\title{
Article \\ Molecular Characterization of Cephalosporin and Fluoroquinolone Resistant Salmonella Choleraesuis Isolated from Patients with Systemic Salmonellosis in Thailand
}

\author{
Pichapak Sriyapai ${ }^{1}$, Chaiwat Pulsrikarn ${ }^{2}$, Kosum Chansiri ${ }^{3}$, Arin Nyamniyom ${ }^{4}$ and Thayat Sriyapai ${ }^{4, *}$ \\ 1 Department of Microbiology, Faculty of Science, Srinakharinwirot University, Bangkok 10110, Thailand; \\ peechapack@g.swu.ac.th \\ 2 WHO International Salmonella and Shigella Center, National Institute of Health, Nonthaburi 11000, Thailand; \\ chaiwat.p@dmsc.mail.go.th \\ 3 Department of Biochemistry, Faculty of Medicine, Srinakharinwirot University, Bangkok 10110, Thailand; \\ kosum@g.swu.ac.th \\ 4 Faculty of Environmental Culture and Ecotourism, Srinakharinwirot University, Bangkok 10110, Thailand; \\ arin@g.swu.ac.th \\ * Correspondence: thayat@g.swu.ac.th; Tel.: +662-664-5000; Fax: +662-260-3275
}

\section{check for}

updates

Citation: Sriyapai, P.; Pulsrikarn, C.; Chansiri, K.; Nyamniyom, A.;

Sriyapai, T. Molecular

Characterization of Cephalosporin

and Fluoroquinolone Resistant

Salmonella Choleraesuis Isolated from Patients with Systemic Salmonellosis in Thailand. Antibiotics 2021, 10, 844. https://doi.org/10.3390/

antibiotics10070844

Academic Editor: Xuanxian Peng

Received: 30 May 2021

Accepted: 6 July 2021

Published: 12 July 2021

Publisher's Note: MDPI stays neutral with regard to jurisdictional claims in published maps and institutional affiliations.

Copyright: (c) 2021 by the authors. Licensee MDPI, Basel, Switzerland. This article is an open access article distributed under the terms and conditions of the Creative Commons Attribution (CC BY) license (https:// creativecommons.org/licenses/by/ $4.0 /)$.
Abstract: The antimicrobial resistance of nontyphoidal Salmonella has become a major clinical and public health problem. Southeast Asia has a high level of multidrug-resistant Salmonella and isolates resistant to both fluoroquinolone and third-generation cephalosporins. The incidence of co-resistance to both drug classes is a serious therapeutic problem in Thailand. The aim of this study was to determine the antimicrobial resistance patterns, antimicrobial resistance genes and genotypic relatedness of third-generation cephalosporins and/or fluoroquinolone-resistant Salmonella Choleraesuis isolated from patients with systemic salmonellosis in Thailand. Antimicrobial susceptibility testing was performed using the agar disk diffusion method, and ESBL production was detected by the combination disc method. A molecular evaluation of $S$. Choleraesuis isolates was performed using PCR and DNA sequencing. Then, a genotypic relatedness study of $S$. Choleraesuis was performed by pulse field gel electrophoresis. All 62 cefotaxime-resistant $S$. Choleraesuis isolates obtained from 61 clinical specimens were multidrug resistant. Forty-four isolates $(44 / 62,71.0 \%)$ were positive for ESBL phenotypes. Based on the PCR sequencing, 21, 1, 13, 23, 20 and 6 ESBL-producing isolates harboured the ESBL genes $b l a_{\mathrm{CTX}-\mathrm{M}-14}, b l a_{\mathrm{CTX}-\mathrm{M}-15}, b l a_{\mathrm{CTX}-\mathrm{M}-55}, b l a_{\mathrm{CMY}-2}, b l a_{\mathrm{ACC}-1}$ and $b l a_{\mathrm{TEM}-1}$, respectively. This study also found that nine $(9 / 62,14.5 \%)$ isolates exhibited co-resistance to ciprofloxacin and cefotaxime. All of the co-resistant isolates harboured at least one PMQR gene. The $q n r$ genes and the $a a c\left(6^{\prime}\right)$-Ib-cr gene were the most prevalent genes detected. The QRDR mutation, including the gyr $A$ (D87Y and D87G) and parC (T57S) genes, was also detected. PFGE patterns revealed a high degree of clonal diversity among the ESBL-producing isolates.

Keywords: antimicrobial resistance; cephalosporin; extended-spectrum $\beta$-lactamase; fluoroquinolone; Salmonella Choleraesuis

\section{Introduction}

Salmonella is one of the most common types of bacteria; it is a human pathogen that causes 'Salmonellosis' and some types of gastroenteritis, including self-limiting enterocolitis, bacteremia, meningitis, and osteomyelitis [1]. More than 2600 different serovars of $S$. enterica have been identified. The microorganisms are transmitted by contaminated food or inadequate food hygiene and the fecal-oral route. Southeast Asia has a high level of multidrug-resistant nontyphoidal Salmonella and isolates resistant to both fluoroquinolone and third-generation cephalosporins $[2,3]$. Compared to previous susceptibility patterns among isolates from Southeast Asia, current nontyphoidal Salmonella infections in humans 
in Thailand are more resistant to fluoroquinolone and cephalosporins [4]. The incidence of co-resistance to both drugs classes is a serious therapeutic problem in Thailand.

The production of extended-spectrum $\beta$-lactamases (ESBLs) is an important resistance mechanism to extended-spectrum cephalosporins (ESCs) in nontyphoidal Salmonella [5]. Salmonella spp. have been found to express a wide variety of ESBL genes, including $b l a_{\mathrm{TEM}}, b l a_{\mathrm{CTX}-\mathrm{M}}, b l a_{\mathrm{SHV}}, b l a_{\mathrm{ACC}}$, and $b l a_{\mathrm{CMY}}[5]$. A previous study reported that most ESBLs are coded by plasmids, some of which also carry genes conferring resistance to fluoroquinolones [6]. To date, several plasmid-mediated quinolone resistance (PMQR) mechanisms have been identified: $q n r$ gene families encode Qnr protection proteins, aac $\left(6^{\prime}\right)$ $I b$-cr gene encodes variant of an aminoglycoside acetyltransferase, and oqxA and oqxAB genes encode a multidrug efflux pump [7]. In addition, the mechanisms of quinolone resistance are chromosomal mutations in the quinolone resistance-determining regions (QRDRs) and consist of either the modification of the quinolone targets with changes in the genes encoding DNA gyrase (gyrA and gyrB) and/or topoisomerase IV (parC and parE) [8]. A high level of drug resistance arises due to alterations in amino acids on each subunit.

In Thailand, the number of patients who are infected with Salmonella enterica serovar Choleraesuis has been increasing. The data show that the prevalence increased from $1.5 \%$ $(n=87)$ in 1994 to $9.2 \%(n=190)$ in 2006. People between the ages of 6 and 40 years in Thailand have the highest risk of infection [4]. In 2007, an increased number of $S$. Choleraesuis isolates from Thailand were fluoroquinolone- and ceftriaxone-resistant [9]. Lee et al. [10] found that isolates from Thailand and Taiwan demonstrated an alarmingly high frequency of resistance to fluoroquinolones and third-generation cephalosporins. A recent Thai study found that the rate of ESC resistance for $S$. Choleraesuis isolated from bacteremic patients increased from $66.7 \%$ in 2010 to $94.1 \%$ in 2014 [11]. However, few studies have reported data on antimicrobial resistance to third-generation cephalosporins and fluoroquinolones in $S$. Choleraesuis in Thailand. Therefore, this study aimed to evaluate the antimicrobial resistance patterns, antimicrobial resistance genes and genotypic relatedness of 62 $S$. Choleraesuis isolates collected from patients with systemic salmonellosis in Thailand during 2010-2015.

\section{Results and Discussions}

\subsection{Antimicrobial Susceptibility and ESBL-Producing S. Choleraesuis Isolates}

A total of $62 S$. Choleraesuis isolates were randomly collected from 61 clinical specimens and used in this study. The majority of $S$. Choleraesuis isolates in this study were recovered from blood specimens which accounted for $83.87 \%$ of all strains. According to data obtained from Thailand, S. Weltevreden, S. Stanley, S. Anatum, and S. Rissen were the most common serovars in patient stool samples. Conversely, $S$. Choleraesuis, $S$. Enteritidis, $S$. Typhimurium, and $S$. Typhi were observed in blood samples [12]. In a previous study in Thailand during 2005, 135 nontyphoidal Salmonella isolated from blood in Siriraj Hospital showed that Salmonella group C (47\%) was the most common serogroup and $17.8 \%, 14.1 \%, 17.8 \%$ and $5.8 \%$ of isolates were resistant to ceftriaxone, ceftazidime cefotaxime and ciprofloxacin, respectively [13]. Furthermore, $S$. Choleraesuis was the most common serovar $(49.3 \%)$ in 414 nontyphoid Salmonella isolates from bacteremic patients in Thailand between 2005 and 2016 [11].

The antimicrobial susceptibility of $62 \mathrm{~S}$. Choleraesuis isolates from patients with systemic infections was evaluated (Table 1). Multidrug resistance (resistance to at least three different classes of antimicrobials) was observed in all isolates. All $S$. Choleraesuis isolates showed reduced susceptibility to 18 antibiotics except for norfloxacin. All isolates were resistant to ampicillin, tetracycline, nalidixic acid and third-generation cephalosporin drugs (ceftriaxone, cefotaxime, ceftriaxone and cefalothin). The susceptibility to antimicrobials was as follows: cefpodoxime $(98.4 \%)$, ceftiofur $(96.8 \%)$, chloramphenicol $(83.9 \%)$, cefuroxime $(80.6 \%)$, streptomycin $(64.5 \%)$, ceftazidime $(62.9 \%)$, aztreonam $(43.5 \%)$, amoxicillin/clavulanate $(43.4 \%)$, cefoxitin $(40.3 \%)$, ciprofloxacin $(14.6 \%)$, trimethoprimsulfamethoxazole (11.3\%) and cefepime (8.1\%). Forty-four $S$. Choleraesuis (44/62 isolates, 
71.1\%) isolates were positive for ESBL phenotypes. All ESBL-producing isolates were resistant to ampicillin, and 100\% were cross-resistant to cefotaxime and cefpodoxime. In total, $18.7 \%$ (12/62 isolates) were resistant to all nine cephalosporin antimicrobials (cefepime, cefoxitin, ceftazidime, cefotaxime, cefpodoxime, cephalothin, cefuroxime, ceftriaxone and ceftiofur). Additionally, 62 isolates (100\%) and 9 isolates $(14.6 \%)$ were resistant to nalidixic acid and ciprofloxacin, respectively. However, this study also found that nine isolates exhibited co-resistance to ciprofloxacin with cefotaxime, ceftriaxone and cefalothin.

Table 1. Antimicrobial susceptibilities of 62 Salmonella Choleraesuis isolates from clinical specimens.

\begin{tabular}{|c|c|c|c|c|}
\hline Antimicrobial & Group & $\begin{array}{l}\text { \% Resistant } \\
\text { (Isolate) }\end{array}$ & $\begin{array}{l}\text { \% Intermediate } \\
\text { (Isolate) }\end{array}$ & $\begin{array}{l}\text { \% Sensitive } \\
\text { (Isolate) }\end{array}$ \\
\hline AMP & penicillin & $100(62)$ & 0 & 0 \\
\hline AMC & $\begin{array}{l}\beta \text {-lactam } / \beta \text {-lactam } \\
\text { inhibitor combination }\end{array}$ & $43.4(30)$ & 0 & $51.6(32)$ \\
\hline ATM & monobactam & $43.5(27)$ & $12.9(8)$ & $43.5(27)$ \\
\hline FEP & cephalosporin & $8.1(5)$ & $21.0(13)$ & $71.0(44)$ \\
\hline CAZ & cephalosporin & $62.9(42)$ & $6.4(4)$ & $25.8(16)$ \\
\hline FOX & cephalosporin & $40.3(25)$ & $4.8(3)$ & $54.8(34)$ \\
\hline CTX & cephalosporin & $100.0(62)$ & 0 & 0 \\
\hline CPD & cephalosporin & $98.4(61)$ & 0 & 0 \\
\hline $\mathrm{KF}$ & cephalosporin & $100(62)$ & 0 & 0 \\
\hline CXM & cephalosporin & $80.6(53)$ & $12.9(8)$ & $1.6(1)$ \\
\hline $\mathrm{CRO}$ & cephalosporin & $100.0(62)$ & 0 & 0 \\
\hline EFT & cephalosporin & $96.8(60)$ & $3.2(2)$ & 0 \\
\hline CIP & fluoroquinolone & $14.6(9)$ & $67.7(42)$ & $17.7(11)$ \\
\hline $\mathrm{CHL}$ & phenicol & $83.9(52)$ & $9.7(6)$ & $6.4(4)$ \\
\hline NA & quinolone & $100.0(62)$ & 0 & 0 \\
\hline NOR & fluoroquinolone & $0.0(0)$ & 0 & $100(62)$ \\
\hline $\mathrm{S}$ & aminoglycoside & $64.5(43)$ & $19.3(12)$ & $11.3(11)$ \\
\hline TET & tetracycline & $100.0(62)$ & 0 & 0 \\
\hline STX & folate Pathway inhibitor & $11.3(7)$ & $1.61(1)$ & $87.1(54)$ \\
\hline
\end{tabular}

AMP, ampicillin; AMC, amoxicillin + clavulanate; CIP, ciprofloxacin; NA, nalidixic acid; ATM, aztreonam; CHL, chloramphenicol; S, streptomycin; TET, tetracycline; SXT, sulfamethoxazole; KF, cefalothin; FOX, Cefoxitin; FEP, cefepime; CXM, cefuroxime; CAZ, ceftazidime; $\mathrm{CTX}$, cefotaxime; $\mathrm{CRO}$, ceftriaxone; $\mathrm{CPD}$, cefpodoxime; $\mathrm{EFT}$, ceftiofur.

Different antimicrobial resistance patterns were found amongst the ESBL $(n=44)$ and non-ESBL $(n=18)$ isolates. There was a difference between the level of antimicrobial resistance in the ESBL-positive and ESBL-negative isolates. A total of 30 different resistance patterns were observed amongst the ESBL and non-ESBL producing $S$. Choleraesuis isolates, which were multidrug-resistant to 9 to 16 antimicrobial agents (Table 2). The most common resistance patterns were AMP-AMC-NA-CHL-S-TET-KF-FOX-CXM-CAZ-EFT-CRO-CPD-CTX (four ESBL isolates and four non-ESBL isolates, 12.9\%) and AMP-AMC-NA-ATM-CHL-S-TET-KFFOX-CXM-CAZ-EFT-CRO-CPD-CTX (two ESBL isolates and six non-ESBL isolates, 12.9\%), followed by AMP-NA-CHL-TET-KF-CXM-EFT-CRO-CPD-CTX (six ESBL isolates, 9.7\%) and AMP-NA-CHL-S-TET-KF-CXM-EFT-CRO-CPD-CTX (four ESBL isolates, 6.4\%). 
Table 2. Antimicrobial resistance patterns of ESBL and non-ESBL producing Salmonella Choleraesuis isolates from clinical specimens.

\begin{tabular}{|c|c|c|}
\hline \multirow{2}{*}{ Antimicrobial Resistance Patterns } & \multicolumn{2}{|c|}{ No. of Isolate (\%) } \\
\hline & ESBL & Non-ESBL \\
\hline \multicolumn{3}{|l|}{9 antimicrobial resistance } \\
\hline AMP-NA-TET-KF-CXM-EFT-CRO-CPD-CTX & $3(4.8 \%)$ & - \\
\hline \multicolumn{3}{|l|}{10 antimicrobial resistance } \\
\hline AMP-NA-CHL-TET-KF-CXM-EFT-CRO-CPD-CTX & $6(9.6 \%)$ & - \\
\hline AMP-NA-CHL-S-TET-KF-CXM-EFT-CPD-CTX & $1(1.6 \%)$ & - \\
\hline \multicolumn{3}{|l|}{11 antimicrobial resistance } \\
\hline AMP-NA-CHL-S-TET-KF-CXM-EFT-CRO-CPD-CTX & $4(6.4 \%)$ & - \\
\hline AMP-NA-ATM-CHL-TET-STX-KF-EFT-CRO-CPD-CTX & $1(1.6 \%)$ & - \\
\hline AMP-NA-TET-KF-FEP-CXM-CAZ-EFT-CRO-CPD-CTX & $1(1.6 \%)$ & - \\
\hline AMP-NA-ATM-TET-KF-CXM-CAZ-EFT-CRO-CPD-CTX & $1(1.6 \%)$ & - \\
\hline AMP-NA-ATM-CHL-TET-KF-CXM-EFT-CRO-CPD-CTX & $1(1.6 \%)$ & - \\
\hline AMP-AMC-NA-CHL-TET-KF-CXM-EFT-CRO-CPD-CTX & $1(1.6 \%)$ & - \\
\hline AMP-CIP-NA-TET-STX-KF-CXM-EFT-CRO-CPD-CTX & $1(1.6 \%)$ & - \\
\hline AMP-AMC-NA-S-TET-KF-FOX-CAZ-CRO-CPD-CTX & - & $1(1.6 \%)$ \\
\hline \multicolumn{3}{|l|}{12 antimicrobial resistance } \\
\hline AMP-CIP-NA-ATM-CHL-TET-KF-CXM-EFT-CRO-CPD-CTX & $1(1.6 \%)$ & - \\
\hline AMP-AMC-NA-CHL-S-TET-KF-FOX-CAZ-CRO-CPD-CTX & $1(1.6 \%)$ & - \\
\hline AMP-NA-S-TET-KF-FEP-CXM-CAZ-EFT-CRO-CPD-CTX & $1(1.6 \%)$ & - \\
\hline AMP-AMC-NA-CHL-S-TET-KF-CAZ-EFT-CRO-CPD-CTX & - & $2(3.2 \%)$ \\
\hline AMP-AMC-NA-TET-KF-FOX-CXM-CAZ-EFT-CRO-CPD-CTX & - & $1(1.6 \%)$ \\
\hline \multicolumn{3}{|l|}{13 antimicrobial resistance } \\
\hline AMP-NA-ATM-CHL-TET-STX-KF-CXM-CAZ-EFT-CRO-CPD-CTX & $2(3.2 \%)$ & - \\
\hline AMP-NA-ATM-CHL-S-TET-KF-CXM-CAZ-EFT-CRO-CPD-CTX & $2(3.2 \%)$ & - \\
\hline AMP-NA-ATM-S-TET-STX-KF-CXM-CAZ-EFT-CRO-CPD-CTX & $1(1.6 \%)$ & - \\
\hline AMP-CIP-NA-ATM-CHL-S-TET-KF-CXM-EFT-CRO-CPD-CTX & $1(1.6 \%)$ & - \\
\hline AMP-AMC-NA-CHL-S-TET-KF-FOX-CAZ-EFT-CRO-CPD-CTX & - & $3(4.8 \%)$ \\
\hline \multicolumn{3}{|l|}{14 antimicrobial resistance } \\
\hline AMP-AMC-NA-CHL-S-TET-KF-FOX-CXM-CAZ-EFT-CRO-CPD-CTX & $4(6.4 \%)$ & $4(6.4 \%)$ \\
\hline AMP-CIP-NA-ATM-CHL-S-TET-KF-CXM-CAZ-EFT-CRO-CPD-CTX & $4(6.4 \%)$ & - \\
\hline AMP-AMC-NA-ATM-CHL-S-TET-KF-FOX-CAZ-EFT-CRO-CPD-CTX & $1(1.6 \%)$ & - \\
\hline \multicolumn{3}{|l|}{15 antimicrobial resistance } \\
\hline AMP-AMC-NA-ATM-CHL-S-TET-KF-FOX-CXM-CAZ-EFT-CRO-CPD-CTX & $2(3.2 \%)$ & $6(9.6 \%)$ \\
\hline AMP-AMC-NA-CHL-S-TET-STX-KF-FOX-CXM-CAZ-EFT-CRO-CPD-CTX & $1(1.6 \%)$ & - \\
\hline AMP-NA-ATM-CHL-S-TET-STX-KF-FEP-CXM-CAZ-EFT-CRO-CPD-CTX & $1(1.6 \%)$ & - \\
\hline AMP-AMC-NA-ATM-CHL-S-TET-KF-FEP-CXM-CAZ-EFT-CRO-CPD-CTX & - & $1(1.6 \%)$ \\
\hline \multicolumn{3}{|l|}{16 antimicrobial resistance } \\
\hline AMP-AMC-CIP-NA-ATM-CHL-S-TET-KF-FOX-CXM-CAZ-EFT-CRO-CPD-CTX & $1(1.6 \%)$ & - \\
\hline AMP-AMC-CIP-NA-ATM-CHL-S-TET-KF-FEP-CXM-CAZ-EFT-CRO-CPD-CTX & $1(1.6 \%)$ & - \\
\hline
\end{tabular}

AMP, ampicillin; AMC, amoxicillin + clavulanate; CIP, ciprofloxacin; NA, nalidixic acid; ATM, aztreonam; CHL, chloramphenicol; S, streptomycin; TET, tetracycline; SXT, sulfamethoxazole; KF, cefalothin; FOX, cefoxitin; FEP, cefepime; CXM, cefuroxime; CAZ, ceftazidime; CTX, cefotaxime; $\mathrm{CRO}$, ceftriaxone; $\mathrm{CPD}$, cefpodoxime; EFT, ceftiofur.

To date, only a few reports from Taiwan and Thailand have described resistance to third-generation cephalosporins and fluoroquinolones in $S$. Choleraesuis $[10,14,15]$. Our data indicate that the rates of antimicrobial resistance against fluoroquinolones and third-generation cephalosporin in $S$. Choleraesuis are increasing when compared to those previously reported in Thailand. A recent study of $54 \mathrm{~S}$. Choleraesuis isolates reports that approximately $60 \%$ of the study isolates were nalidixic acid-resistant and $15 \%$ were ceftriaxone-resistant [9]. Furthermore, a high rate of ceftriaxone (58.3\%) and ciprofloxacin $(19.6 \%)$ resistance was reported in $S$. Choleraesuis isolated from bacteremia patients in Thailand during 2005-2007 and 2012-2016 [11].

\subsection{Characterization of the ESBL, $Q R D R$ and $P M Q R$ Genes}

This study provides a description of the diversity of $\beta$-lactamase-resistant gene patterns in S. Choleraesuis isolates from patients with systemic infection in Thailand. The 
characteristics of plasmid-mediated ESBL-producing $S$. Choleraesuis isolates are shown in Figure 1. All ESBL-producing isolates have 13 patterns of $\beta$-lactamase-resistant genes. Based on PCR sequencing, 35, 23, 20 and 6 ESBL-producing isolates harboured the ESBL genes encoding CTX-M, CMY-2, ACC and TEM-1, respectively. Within the CTX-M family, the CTX-M-9 group is more prevalent than the CTX-M-1 group. The CTX-M-1 and CTX-M-9 groups were represented by CTX-M-55 (13 isolates) or CTX-M-15 (1 isolates) and CTX-M-14 (21 isolates), respectively. The bla $a_{\mathrm{OXA}}$ and bla $a_{\mathrm{SHV}}$ genes were also targeted, but there were no positive results. The occurrence of ESBL phenotypes and genotypes in this study was similar to those of other studies in Taiwan and Thailand [16,17]. The $b l a_{\mathrm{CTX}-\mathrm{M}-14}$ and $b l a_{\mathrm{CMY}-2}$ genes were found in extended-spectrum cephalosporinaseproducing $S$. Choleraesuis isolates recovered from Thai patients [17]. The $b l a_{\mathrm{CMY}-2}$ gene for ampicillin resistance was also reported in ESC-resistant $S$. Choleraesuis strains isolated in Taiwan in 2006 [14] and Thailand during 2005-2007 [11]. A previous paper has reported that plasmids harbouring the $b l a_{\mathrm{CTX}-\mathrm{M}-14}, b l a_{\mathrm{CTX}-\mathrm{M}-15}$ and $b l a_{\mathrm{CTX}-\mathrm{M}-55}$ genes were found in $S$. Typhimurium isolates from paediatric patients in China [18]. To our knowledge, there was only one previous article that reported the dissemination of CTX-M-55-producing $S$. Choleraesuis isolates from ESC-resistant $S$. Choleraesuis clinical isolates in Thailand during 2012-2016 [11]. In the past, plasmids carrying bla $a_{\mathrm{CTX}-\mathrm{M}-55}$ and bla $a_{\mathrm{CTX}-\mathrm{M}-15}$ have been found in ESBL-producing E. coli and Klebsiella in China and Thailand $[19,20]$. The molecular characterization showed that $b l a_{\mathrm{CTX}} \mathrm{M}-55$ is a derivative of $b l a_{\mathrm{CTX}-\mathrm{M}-15}$, in which the Ala in position 77 is substituted with a Val. With regard to antibiotic resistance, the MIC ranges for cefotaxime, ceftazidime, ceftriaxone and cefpodoxime of isolates carrying the bla $a_{\mathrm{CTX}-\mathrm{M}-55}$ and $b l a_{\mathrm{CTX}} \mathrm{M}-15$ genes were significantly higher than those of isolates carrying bla $a_{\mathrm{CTX}-\mathrm{M}-14}$. The bla $a_{\mathrm{CTX}-\mathrm{M}-15}$ and $b l a_{\mathrm{CTX}-\mathrm{M}-55}$ are the main genes that cause ceftazidime resistance [19]. Ceftazidime-hydrolysing CTX-M-15 and CTX-M-55 enzymes possess a Gly substitution in position 240, which may be associated with a reduced susceptibility to ceftazidime [21]. The data suggest that ESBL-producing isolates have emerged in Thailand on several plasmids and in multiple clones of $S$. Choleraesuis. The clonal spread of CTX-M-mediated resistance may be due to horizontal transfer, but this study did not perform gene or plasmid transfer experiments on our ESBL-producing isolates. However, an epidemiological study of plasmid transfer between bacteria in the Enterobacteriaceae family has been reported previously $[19,20]$. In intensive health-care hospital settings, the development and spread of ESBL genes has most likely been caused or at least facilitated by the overuse of antibiotic drugs [22].

In addition, 20.5\% (9/44 isolates) of the ESBL-producing isolates were also co-resistant to ciprofloxacin (Table 3). All co-resistant isolates displayed a QRDR mutation in the gyr $A$ (D87Y and D87G) and parC (T57S) genes. The most frequently observed point mutations of the gyrA gene in fluoroquinolone-resistant Salmonella are the amino acid changes at serine- 83 to phenylalanine, tyrosine, or alanine, or at aspartic acid- 87 to glycine, asparagine, or tyrosine [23]. Mutations in $\operatorname{parC}$ genes have been found in fluoroquinolone-resistant S. Choleraesuis [14]. Of the nine isolates, seven patterns of PMQR genes were identified, all of the co-resistant isolates harboured at least one PMQR gene; the $q n r$ genes ( $q n r A$ or/and $q n r B$ or/and $q n r S$ ) and the $a a c\left(6^{\prime}\right)$ - $I b-c r$ gene were the most prevalent resistance genes detected. Based on the MICs of the tested cephalosporins, the MIC values of coresistant isolates for cefotaxime, ceftazidime, ceftriaxone, and cefpodoxime ranged from 64 to $\geq 256 \mu \mathrm{g} / \mathrm{mL}, 1$ to $48 \mu \mathrm{g} / \mathrm{mL}, \geq 256 \mu \mathrm{g} / \mathrm{mL}$, and 32 to $\geq 256 \mu \mathrm{g} / \mathrm{mL}$, respectively. In addition, four strains isolated from the blood samples showed high MIC levels for ciprofloxacin $(2 \mu \mathrm{g} / \mathrm{mL})$. Only one strain in a 40-year-old patient, SH575/12, showed high MIC levels for both ciprofloxaxin (MIC $2 \mu \mathrm{g} / \mathrm{mL}$ ) and cephalosporins (cefotaxime $\geq 256 \mu \mathrm{g} / \mathrm{mL}$, ceftazidime $=48 \mu \mathrm{g} / \mathrm{mL}$, ceftriaxone $\geq 256 \mu \mathrm{g} / \mathrm{mL}$ and cefpodoxime $\geq 256 \mu \mathrm{g} / \mathrm{mL}$ ). This strain contained two types of ESBL genes (bla $a_{\mathrm{TEM}-1}$ and bla $\left._{\mathrm{CTX}-\mathrm{M}-55}\right)$, four types of PMQR genes ( $q n r A$, qnrB, qnrS and $\left.a a c\left(6^{\prime}\right)-l b-c r\right)$ and presented a mutation in both $g y r A$ and parC. However, an earlier study demonstrated fluoroquinolone and ESC resistance in $S$. Choleraesuis isolated from bacteremic patients in Thailand in 2003-2005 [9]. In this study, four 
co-resistant isolates obtained from three patients with a systemic infection showed a higher MIC for ciprofloxacin $(2 \mu \mathrm{g} / \mathrm{mL})$ than previously reported, which reduced the susceptibility to ciprofloxacin to $\geq 0.125 \mu \mathrm{g} / \mathrm{mL}$ [9].

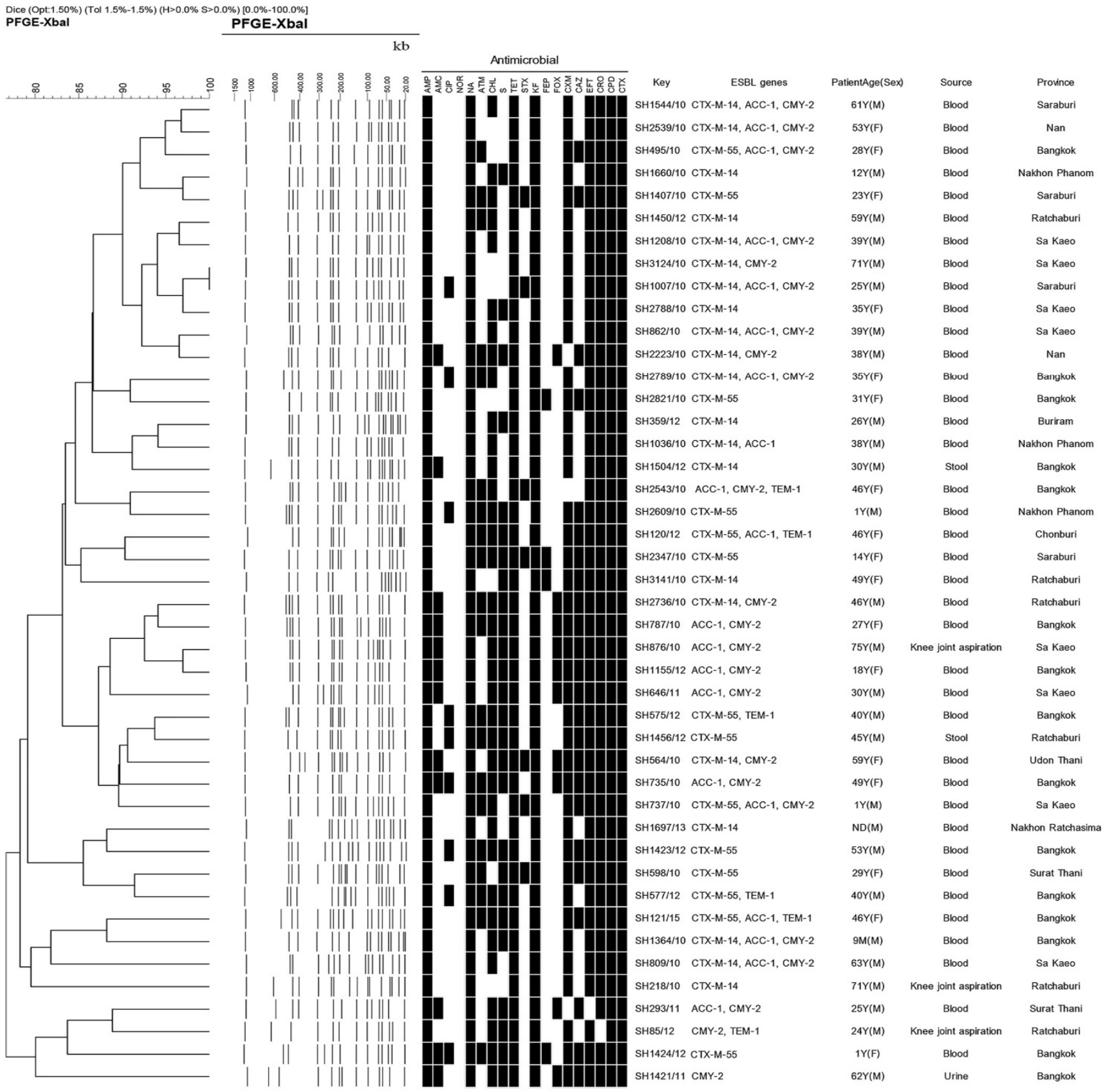

Figure 1. PFGE characteristics and ESBL genes of 44 ESBL-producing Salmonella Choleraesuis isolates.

Table 3. Phenotypic and genotypic features of the co-resistant Salmonella Choleraesuis isolates.

\begin{tabular}{|c|c|c|c|c|c|c|c|c|c|}
\hline \multirow[t]{2}{*}{ LabID } & \multirow{2}{*}{$\begin{array}{c}\text { MIC CIP } \\
(32- \\
0.002 \mu \mathrm{g} / \mathrm{mL})\end{array}$} & \multicolumn{2}{|c|}{ QRDR Mutation in: } & \multirow[t]{2}{*}{ PMQR } & \multicolumn{4}{|c|}{$\begin{array}{l}\text { MIC Cephalosporin } \\
(256-0.016 \mu \mathrm{g} / \mathrm{mL})\end{array}$} & \multirow[t]{2}{*}{ ESBL Gene } \\
\hline & & gyrA & parC & & CTX & CAZ & CRO & CPD & \\
\hline SH1007 & 0.25 & D87Y & T57S & $q n r A, q n r S 1$ & 128 & 1.5 & $\geq 256$ & 96 & $\begin{array}{c}\text { bla } a_{\mathrm{CTX}-\mathrm{M}-14} \\
\text { bla }_{\mathrm{ACC}-1} \\
\text { bla }_{\mathrm{CMY}-2}\end{array}$ \\
\hline SH2609 & 2 & D87G & T57S & $\begin{array}{l}q n r B, q n r S 1, \\
\operatorname{aac}\left(6^{\prime}\right)-l b-c r\end{array}$ & $\geq 256$ & 32 & $\geq 256$ & $\geq 256$ & $b l a_{\mathrm{CTX}} \mathrm{M}-55$ \\
\hline SH2789 & 0.5 & D87Y & T57S & $\begin{array}{l}q n r A, q n r B, q n r S 1, \\
\operatorname{aac}\left(6^{\prime}\right)-l b-c r\end{array}$ & 64 & 1 & $\geq 256$ & 32 & $\begin{array}{c}b^{b} a_{\mathrm{CTX}-\mathrm{M}-14} \\
\text { bla }_{\mathrm{ACC}-1} \\
\text { bla }_{\mathrm{CMY}-2}\end{array}$ \\
\hline
\end{tabular}


Table 3. Cont.

\begin{tabular}{|c|c|c|c|c|c|c|c|c|c|}
\hline \multirow[t]{2}{*}{ LabID } & \multirow{2}{*}{$\begin{array}{c}\text { MIC CIP } \\
(32- \\
0.002 \mu \mathrm{g} / \mathrm{mL})\end{array}$} & \multicolumn{2}{|c|}{ QRDR Mutation in: } & \multirow[t]{2}{*}{ PMQR } & \multicolumn{4}{|c|}{$\begin{array}{l}\text { MIC Cephalosporin } \\
(256-0.016 \mu \mathrm{g} / \mathrm{mL})\end{array}$} & \multirow[t]{2}{*}{ ESBL Gene } \\
\hline & & gyrA & parC & & CTX & CAZ & CRO & CPD & \\
\hline SH735 & 2 & D87Y & T57S & $q n r S 1, a a c\left(6^{\prime}\right)-l b-c r$ & 64 & 32 & $\geq 256$ & 32 & $\begin{array}{l}\text { bla }_{\mathrm{ACC}-1} \\
\text { bla }_{\mathrm{CMY}-2}\end{array}$ \\
\hline SH575 & 2 & D87G & T57S & $\begin{array}{c}q n r A, q n r B, q n r S 1, \\
\operatorname{aac}\left(6^{\prime}\right)-l b-c r\end{array}$ & $\geq 256$ & 48 & $\geq 256$ & $\geq 256$ & $\begin{array}{c}b l a_{\mathrm{CTX}-\mathrm{M}-55} \\
\text { bla }_{\mathrm{TEM}-1}\end{array}$ \\
\hline SH1423 & 0.5 & D87G & T57S & $\begin{array}{l}q n r S 1, q n r B \\
a a c\left(6^{\prime}\right)-l b-c r\end{array}$ & $\geq 256$ & 32 & $\geq 256$ & $\geq 256$ & $b l a_{\mathrm{CTX}-\mathrm{M}-55}$ \\
\hline SH577 & 2 & D87G & T57S & $q n r A, q n r B, q n r S 1$ & $\geq 256$ & 32 & $\geq 256$ & $\geq 256$ & 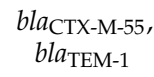 \\
\hline SH1424 & 0.12 & D87G & T57S & $\begin{array}{c}q n r A, q n r B, q n r S 1, \\
a a c\left(6^{\prime}\right)-l b-c r\end{array}$ & $\geq 256$ & 48 & $\geq 256$ & $\geq 256$ & $b l a_{\mathrm{CTX}-\mathrm{M}-15}$ \\
\hline SH1456 & 0.25 & D87G & T57S & $\begin{array}{l}q n r A, q n r S 1 \\
\operatorname{aac}\left(6^{\prime}\right)-l b-c r\end{array}$ & $\geq 256$ & 32 & $\geq 256$ & $\geq 256$ & $b l a_{\mathrm{CTX}}-\mathrm{M}-55$ \\
\hline
\end{tabular}

CTX, cefotaxime; CAZ, ceftazidime; CRO, ceftriaxone; and CPD, cefpodoxim; $\mathrm{D}$, aspartic acid; $\mathrm{G}$, glycine; $\mathrm{S}$, serine; $\mathrm{T}$, threonine; $\mathrm{Y}$, tyrosine.

\subsection{PFGE Analysis}

After digestion by the XbaI enzyme, the genetic relatedness of ESBL-producing $S$. Choleraesuis isolates was evaluated by PFGE. The dendrograms in Figure 1 demonstrate the banding patterns and the genetic relatedness of the isolates evaluated by PFGE. Multidrug antimicrobial resistance patterns and ESBL genes were also reported. Thirty-one fingerprint-patterns generated by PFGE were identified amongst the strains recovered from various locations at different times and source isolation, providing information on associations amongst the ESBL-producing strains and evidence of the diversity of ESBL genes harboured on plasmids in Thailand. Forty-four isolates were clustered into six predominant PFGE pulsotypes with $\geq 2$ indistinguishable isolates, which showed a close relationship (Dice correlation coefficient of 95\%) based on Tenover criteria [24]. However, this study represented a high diversity of PFGE fingerprint patterns of ESBL-producing $S$. Choleraesuis isolates in Thailand. The PFGE and antimicrobial resistance patterns revealed a high degree of clonal diversity amongst the 44 ESBL-producing isolates. All of the analyses indicate that multiple clones and multiple resistance genes on the plasmids are responsible for the extended-spectrum cephalosporin resistance amongst the $S$. Choleraesuis isolates obtained from patients in Thailand. Similarly, Sirichote et al. [16] reported multiple clones and multiple ESBL resistance genes of $S$. Choleraesuis isolates obtained from patients in Thailand and one patient in Denmark. In addition, 16 unique XbaI PFGE patterns of $22 \mathrm{~S}$. Choleraesuis isolates were obtained.

\section{Materials and Methods}

\subsection{Data Source and Salmonella Strains}

Pure cultures of cefotaxime-resistant $S$. Choleraesuis were obtained from the WHO National Salmonella and Shigella Center in Thailand, which were collected from S. Choleraesuis isolated on all regions of Thailand. They were selected isolates from patients with systemic salmonellosis in all regions of Thailand during 2010-2015. A total of 62 cefotaxime-resistant $S$. Choleraesuis isolates used in this study were isolated from 61 clinical specimens. $S$. Choleraesuis isolates were obtained from blood $(n=53)$ and other sources (knee joint aspiration $(n=3)$, pus $(n=2)$, stool $(n=2)$, urine $(n=1)$ and thigh swabs $(n=1))$. The stock culture of $S$. Choleraesuis isolates were re-subcultured to check the purity and were confirmed serovar according to the Kauffmann-White antigen schema [25]. The colonies of $S$. Choleraesuis on xylose lysine deoxycholate agar (XLD agar) appeared colourless, without a black centre. The biochemical test, lysine indole motility (LIM) medium and triple sugar ion (TSI) agar were used for the preliminary identification of $S$. Choleraesuis. The LIM results for $S$. Choleraesuis revealed positive results for lysine decarboxylase and motility, but negative results for indole. The TSI results were presented as alkaline (red) slant and acid butt (yellow), gas positive, and hydrogen sulphide negative. 


\subsection{Antimicrobial Susceptibility Testing}

S. Choleraesuis isolates were tested for susceptibility to antimicrobial agents using the agar disk diffusion method (Kirby Bauer test) following the guidelines and criteria of the Clinical and Laboratory Standards Institute (CLSI) [26]. The antibiotics tested (Oxoid, England) were ampicillin (10 $\mu \mathrm{g})$, amoxicillin-calvulanic acid $(20 / 10 \mu \mathrm{g})$, aztreonam $(30 \mu \mathrm{g})$, cefepime $(30 \mu \mathrm{g})$, ceftazidime $(30 \mu \mathrm{g})$, cefoxitin $(30 \mu \mathrm{g})$, cefotaxime $(30 \mu \mathrm{g})$, cefpodoxime $(10 \mu \mathrm{g})$, cephalothin $(30 \mu \mathrm{g})$, cefuroxime $(30 \mu \mathrm{g})$, ceftriaxone $(30 \mu \mathrm{g})$, ceftiofur $(30$ $\mu \mathrm{g})$, ciprofloxacin $(5 \mu \mathrm{g})$, chloramphenicol $(30 \mu \mathrm{g})$, nalidixic acid $(30 \mu \mathrm{g})$, norfloxacin $(10$ $\mu \mathrm{g})$, streptomycin $(10 \mu \mathrm{g})$, tetracycline $(30 \mu \mathrm{g})$, and trimethoprim/sulfamethoxazole (25 $\mu \mathrm{g})$. Furthermore, cefotaxime-resistant $S$. Choleraesuis isolates were screened for ESBL producers by the combination disk method (CLSI, 2008) [12]. The MICs for ciprofloxacin (32-0.002 $\mu \mathrm{g} / \mathrm{mL})$, cefotaxime $(256-0.016 \mu \mathrm{g} / \mathrm{mL})$, ceftazidime $(256-0.016 \mu \mathrm{g} / \mathrm{mL})$, ceftriaxone $(256-0.016 \mu \mathrm{g} / \mathrm{mL})$ and cefpodoxime $(256-0.016 \mu \mathrm{g} / \mathrm{mL})$ were determined using the Liofilchem MIC test strip (Liofilchem, Roseto degli Abruzzi, Italy), according to the manufacturer's instructions. Escherichia coli ATCC 25922 was used as the quality control strain for antimicrobial susceptibility testing.

\subsection{Characterization of ESBL, QRDR and PMQR Genes}

DNA was extracted by the Wizard ${ }^{\circledR}$ Genomic DNA purification kit (Promega, Madison, WI, USA). All primers used for this study are listed in Table 1. The Ex Taq DNA polymerase (Takara Bio Inc., Japan) was used for the detection of ESBL, QRDR and PMQR genes. The ESBL genes, including $b l a_{\mathrm{TEM}}, b l a_{\mathrm{SHV}}, b l a_{\mathrm{CTX}-\mathrm{M}}, b l a_{\mathrm{ACC}}$, and $b l a_{\mathrm{CMY}-2}$, were amplified by PCR [27-29]. The amplification conditions for the bla $a_{\mathrm{TEM}}, b_{\mathrm{SHV}}$, bla $_{\mathrm{CTX}-\mathrm{M}}$, $b l a_{\mathrm{ACC}}$, and $b l a_{\mathrm{CMY}} 2$ genes were standardised as follows: an initial denaturation at $95^{\circ} \mathrm{C}$ for $5 \mathrm{~min}$, followed by 30 cycles of denaturation at $98^{\circ} \mathrm{C}$ for $10 \mathrm{~s}$, annealing at $55^{\circ} \mathrm{C}$ for $1 \mathrm{~min}$ and DNA extension at $72{ }^{\circ} \mathrm{C}$ for $1.30 \mathrm{~min}$, with a final extension at $72{ }^{\circ} \mathrm{C}$ for $10 \mathrm{~min}$. For confirmation, the CTX group was amplified and sequenced by the bla $a_{\mathrm{CTX}-\mathrm{M}-1}$ group, the $b l a_{\mathrm{CTX}-\mathrm{M}-2}$ group, the $b l a_{\mathrm{CTX}-\mathrm{M}-8 / 25}$ group, the $b l a_{\mathrm{CTX}-\mathrm{M}-9}$ group and the $b l a_{\mathrm{CTX}-\mathrm{M}-15}$ primer $[30,31]$. The PCR program consisted of an initial denaturation at $95^{\circ} \mathrm{C}$ for $5 \mathrm{~min}$, followed by 30 cycles of denaturation at $98^{\circ} \mathrm{C}$ for $10 \mathrm{~s}$, annealing at $55^{\circ} \mathrm{C}$ for the bla CTX-M-1, bla $a_{\mathrm{CTX}-\mathrm{M}-2}, b l a_{\mathrm{CTX}-\mathrm{M}-9}$ groups and $b l a_{\mathrm{CTX}-\mathrm{M}-8 / 25}$ groups, and $50^{\circ} \mathrm{C}$ for $b l a_{\mathrm{CTX}-\mathrm{M}-15}$ for $1 \mathrm{~min}$ with a DNA extension at $72{ }^{\circ} \mathrm{C}$ for $1.30 \mathrm{~min}$, followed by a final extension at $72{ }^{\circ} \mathrm{C}$ for $10 \mathrm{~min}$. The presence of QRDR mutations in $g y r A$ and $\operatorname{par} C$ genes and screening for PMQR, including the $q n r A, q n r B$, qnrS, and $a a c\left(6^{\prime}\right)-l b$-cr genes, were amplified by PCR [32-34]. The amplification conditions for all the PCRs were as follows: an initial denaturation at $95^{\circ} \mathrm{C}$ for $5 \mathrm{~min}$, followed by 30 cycles of denaturation at $98^{\circ} \mathrm{C}$ for $10 \mathrm{~s}$, annealing at $55^{\circ} \mathrm{C}(\operatorname{parC}$, qnr $A$, $q n r S$, and $\left.a a c\left(6^{\prime}\right)-l b-c r\right)$ and $50^{\circ} \mathrm{C}(g y r A$ and $q n r B)$ for $1 \mathrm{~min}$ and DNA extension at $72{ }^{\circ} \mathrm{C}$ for $1.30 \mathrm{~min}$, with a final extension at $72{ }^{\circ} \mathrm{C}$ for $10 \mathrm{~min}$. All PCR products were purified for sequencing using nucleospin gel extraction (Macherey-Nagel, GmbH \& Co. KG, Düren, Germany) and were ran using an automatic sequencer at the Macrogen Inc. (Seoul, Korea). The nucleotide sequence analyses were compared to nucleotide database sequences using the megablast search and to published protein databases using Blastx from the National Center for Biotechnology Information website (https: / /blast.ncbi.nlm.nih.gov/Blast.cgi, accessed on 21 January 2021).

\subsection{Pulse-Field gel Electrophoresis (PFGE)}

All ESBL-producing isolates included in this study were analysed for epidemiological relatedness by PFGE using XbaI according to the Centers for Disease Control and Prevention (CDC) PulseNet protocol [35]. S. Braenderup H9812 was used as a standard marker. The electrophoresis was performed with a CHEF-DR III instrument using the following condition: one pulse time of 2.2 to $63.8 \mathrm{~s}$ for $19 \mathrm{~h}$. The gel was stained with ethidium bromide, and the DNA bands were visualised with a UV transilluminator. The PFGE profile was analysed by BioNumerics software version 3.0 (Bio-Rad). The similarity index was calculated using the Dice correlation coefficient option of the software with a position 
tolerance of $1 \%$ and an optimization of $0.5 \%$. The dendrogram was created using the unweighted-pair group method with average linkages (UPGMA).

\section{Conclusions}

The present study showed a high occurrence of ESBL producers among $S$. Choleraesuis isolated from patients with systemic salmonellosis in Thailand during 2010-2015. In addition, ESBL-producing isolates showed co-resistance to ESCs and fluoroquinolone. The current study describes the diversity of ESBL genes and identifies QRDR mutations and PMQR genes in ESBL-producing $S$. Choleraesuis. The PFGE typing suggests that ESBLproducing $S$. Choleraesuis strains isolated from patients in different regions in Thailand are multiple clones, which may indicate that isolates of this serovar have spread and that resistance has evolved locally among the isolates in Thailand.

Author Contributions: Conceptualization, T.S. and P.S.; methodology, T.S., K.C., A.N. and C.P.; software, T.S. and C.P.; validation, T.S., C.P. and K.C.; formal analysis, C.P. and P.S.; investigation, C.P. and P.S.; resources, C.P.; data curation, T.S. and C.P.; writing-original draft preparation, P.S.; writing-review and editing, T.S., C.P., A.N. and K.C.; visualization, T.S., C.P. and K.C.; supervision, T.S., C.P. and K.C.; project administration, P.S., C.P., A.N., K.C. and T.S.; funding acquisition, T.S. All authors have read and agreed to the published version of the manuscript.

Funding: This research was funded by the 2015 research fund of Srinakharinwirot University, grant no. $077 / 2559$.

Institutional Review Board Statement: Not applicable.

Informed Consent Statement: Not applicable.

Data Availability Statement: Data is contained within the article.

Acknowledgments: The author sincerely thank to the staff of the WHO Salmonella and Shigella Center, National Institute of Health, Department of Medical Sciences, Thailand for their cooperation and helpful.

Conflicts of Interest: The authors declare no conflict of interest.

\section{References}

1. Su, L.H.; Chiu, C.H. Salmonella: Clinical importance and evolution of nomenclature. Chang Gung Med. J. 2007, 30, $210-219$.

2. Collard, J.M.; Place, S.; Denis, O.; Rodriguez-Villalobos, H.; Vrints, M.; Weill, F.X.; Baucheron, S.; Cloeckaert, A.; Struelens, M.; Bertrand, S. Travel-acquired salmonellosis due to Salmonella Kentucky resistant to ciprofloxacin, ceftriaxone and co-trimoxazole and associated with treatment failure. J. Antimicrob. Chemother. 2007, 60, 190-192. [CrossRef] [PubMed]

3. Lauderdale, T.L.; Aarestrup, F.M.; Chen, P.C.; Lai, J.F.; Wang, H.Y.; Shiau, Y.R.; Huang, I.W.; Hung, C.L. Multidrug resistance among different serotypes of clinical Salmonella isolates in Taiwan. Diagn. Microbiol. Infect. Dis. 2006, 255, 149-155. [CrossRef] [PubMed]

4. Hendriksen, R.S.; Bangtrakulnonth, A.; Pulsrikarn, C.; Pornreongwong, S.; Hasman, H.; Song, S.W.; Aarestrup, F.M. Antimicrobial resistance and molecular epidemiology of Salmonella Rissen from animals, food products and patients in Thailand and Denmark. Foodborne Pathog. Dis. 2008, 5, 605-619. [CrossRef]

5. Bush, K.; Jacoby, G.A. Updated functional classification of beta-lactamases. Antimicrob. Agents Chemother. 2010, 54, 969-976. [CrossRef] [PubMed]

6. Boyd, D.A.; Tyler, S.; Christianson, S.; McGeer, A.; Muller, M.P. Complete nucleotide sequence of a 92-kilobase plasmid harboring the CTX-M-15 extended-spectrum beta-lactamase involved in an outbreak in long-term-care facilities in Toronto, Canada. Antimicrob. Agents Chemother. 2004, 48, 3758-3764. [CrossRef]

7. Rodríguez-Martínez, J.M.; Cano, M.E.; Velasco, C.; Martínez-Martínez, L.; Pascual, A. Plasmid-mediated quinolone resistance: An update. J. Infect. Chemother. 2011, 17, 149-182. [CrossRef] [PubMed]

8. Giraud, E.; Baucheron, S.; Cloeckaert, A. Resistance to fluoroquinoloes in Salmonella: Emerging mechanisms and resistance prevention strategies. Microbes Infect. 2006, 8, 1937-1944. [CrossRef]

9. Kulwichit, W.; Chatsuwan, T.; Unhasuta, C.; Pulsrikarn, C.; Bangtrakulnonth, A.; Chongthaleong, A. Drug-resistant nontyphoidal Salmonella bacteremia, Thailand. Emerg. Infect. Dis. 2007, 13, 501-502. [CrossRef]

10. Lee, H.Y.; Su, L.H.; Tsai, M.H.; Kim, S.W.; Chang, H.H.; Jung, S.I.; Park, K.H.; Perera, J.; Carlos, C.; Tan, B.H.; et al. High rate of reduced susceptibility to ciprofloxacin and ceftriaxone among nontyphoid Salmonella clinical isolates in Asia. Antimicrob. Agents Chemother. 2009, 53, 2696-2699. [CrossRef] 
11. Luk-In, S.; Chatsuwan, T.; Pulsrikarn, C.; Bangtrakulnonth, A.; Rirerm, U.; Kulwichit, W. High prevalence of ceftriaxone resistance among invasive Salmonella enterica serotype Choleraesuis isolates in Thailand: The emergence and increase of CTX-M-55 in ciprofloxacin-resistant S. Choleraesuis isolates. Int. J. Med. Microbiol. 2018, 308, 447-453. [CrossRef]

12. Hendriksen, R.S.; Bangtrakulnonth, A.; Pulsrikarn, C.; Pornruangwong, S.; Noppornphan, G.; Emborg, H.D.; Aarestrup, F.M. Risk factors and epidemiology of the ten most common Salmonella serovars from patients in Thailand: 2002-2007. Foodborne Pathog. Dis. 2009, 6, 1009-1019. [CrossRef]

13. Kiratisin, P. Bacteraemia due to non-typhoidal Salmonella in Thailand: Clinical and microbiological analysis. Trans. R. Soc. Trop. Med. Hyg. 2008, 102, 447-450. [CrossRef] [PubMed]

14. Yan, J.J.; Chiou, C.S.; Lauderdale, T.L.; Tsai, S.H.; Wu, J.J. Cephalosporin and ciprofloxacin resistance in Salmonella, Taiwan. Emerg. Infect. Dis. 2005, 11, 947-950. [CrossRef]

15. Chiu, C.H.; Su, L.H.; Chu, C.; Chia, J.H.; Wu, T.L.; Lin, T.Y.; Lee, Y.S.; Ou, J.T. Isolation of Salmonella enterica serotype Choleraesuis resistant to ceftriaxone and ciprofloxacin. Lancet 2004, 363, 1285-1286. [CrossRef]

16. Li, W.C.; Huang, F.Y.; Liu, C.P.; Weng, L.C.; Wang, N.Y.; Chiu, N.C.; Chiang, C.S. Ceftriaxone resistance of nontyphoidal Salmonella enterica isolates in Northern Taiwan attributable to production of CTX-M-14 and CMY-2 beta-lactamases. J. Clin. Microbiol. 2005, 43, 3237-3243. [CrossRef] [PubMed]

17. Sirichote, P.; Hasman, H.; Pulsrikarn, C.; Schønheyder, H.C.; Samulioniené, J.; Pornruangmong, S.; Bangtrakulnonth, A.; Aarestrup, F.M.; Hendriksen, R.S. Molecular characterization of extended spectrum cephalosporinase-Producing Salmonella enterica serovar Choleraesuis isolates from patients in Thailand and Denmark. J. Clin. Microbiol. 2010, 48, 883-888. [CrossRef]

18. Yu, F.; Chen, Q.; Yu, X.; Li, Q.; Ding, B.; Yang, L.; Chen, C.; Qin, Z.; Parsons, C.; Zhang, X.; et al. High prevalence of extendedspectrum beta-lactamases among Salmonella enterica Typhimurium isolates from pediatric patients with diarrhea in China. PLoS ONE 2011, 6, e16801. [CrossRef]

19. Kiratisin, P.; Apisarnthanarak, A.; Saifon, P.; Laesripa, C.; Kitphati, R.; Mundy, L.M. The emergence of a novel ceftazidime-resistant CTX-M extended-spectrum $\beta$-lactamase, CTX-M-55, in both community-onset and hospital-acquired infections in Thailand. Diagn. Microbiol. Infect. Dis. 2007, 58, 349-355. [CrossRef]

20. Shi, W.F.; Zhou, J.; Qin, J.P. Transconjugation and genotyping of the plasmid-mediated AmpC beta-lactamase and extendedspectrum beta-lactamase genes in Klebsiella pneumoniae. Chin. Med. J. 2009, 122, 1092-1096.

21. Cartelle, M.; Del Mar Tomas, M.; Pertega, S.; Beceiro, A.; Dominguez, M.A.; Velasco, D.; Molina, F.; Villanueva, R.; Bou, G. Risk factors for colonization and infection in a hospital outbreak caused by a strain of Klebsiella pneumoniae with reduced susceptibility to expanded-spectrum cephalosporins. J. Clin. Microbiol. 2004, 42, 4242-4249. [CrossRef]

22. Laxminarayan, R.; Duse, A.; Wattal, C.; Zaidi, A.K.; Wertheim, H.F.; Sumpradit, N.; Vlieghe, E.; Hara, G.L.; Gould, I.M.; Goossens, H.; et al. Antibiotic resistance: The need for global solutions. Lancet Infect. Dis. 2013, 13, 1057-1098. [CrossRef]

23. Cloeckaert, A.; Chaslus-Dancla, E. Mechanisms of quinolone resistance in Salmonella. Vet. Res. 2001, 32, 291-300. [CrossRef] [PubMed]

24. Tenover, F.C.; Arbeit, R.D.; Goering, R.V.; Mickelsen, P.A.; Murray, B.E.; Persing, D.H.; Swaminathan, B. Interpreting chromosomal DNA restriction patterns produced by pulsed-field gel electrophoresis: Criteria for bacterial strain typing. J. Clin. Microbiol. 1995, 33, 2233-2239. [CrossRef]

25. Minor, L.; Popoff, M.Y. Request for an opinion; designation of Salmonella enterica sp. Nor, nom. Rev, as the type and only species of the genus Salmonella. Int. J. Syst. Bacteriol. 1987, 37, 465-468. [CrossRef]

26. Clinical and Laboratory Standards Institute. Performance Standards for Antimicrobial Disk and Dilution Susceptibility Tests for Bacteria Isolated from Animals, 3rd ed.; Approved standard, M31-A3; Clinical and Laboratory Standards Institute: Wayne, PA, USA, 2008.

27. Olesen, I.; Hasman, H.; Aarestrup, F.M. Prevalence of $\beta$-lactamases among ampicillin resistant Escherichia coli and Salmonella isolated from food animals in Denmark. Microb. Drug Resist. 2004, 10, 334-340. [CrossRef]

28. Hasman, H.; Mevius, D.; Veldman, K.; Olesen, I.; Aarestrup, F.M. Beta-lactamases among extended-spectrum beta-lactamase (ESBL)-resistant Salmonella from poultry, poultry products and human patients in The Netherlands. J. Antimicrob. Chemother. 2005, 56, 115-121. [CrossRef] [PubMed]

29. Navarro, F.; Miró, E. Update on CTX-M-type $\beta$-lactamases. Rev. Med. Microbiol. 2002, 13, 63-73. [CrossRef]

30. Le, Q.P.; Ueda, S.; Nguyen, T.N.; Dao, T.V.; van Hoang, T.A.; Tran, T.T.; Hirai, I.; Nakayama, T.; Kawahara, R.; Do, T.H.; et al. Characteristics of extended-spectrum $\beta$-lactamase-producing Escherichia coli in retail meats and shrimp at a local market in Vietnam. Foodborne Pathog. Dis. 2015, 12, 719-725. [CrossRef] [PubMed]

31. Munday, C.J.; Ensor, V.M.; Liu, W.E.; Hawkey, P.M. Multiplex PCR detection of CTX-M gene. Clin. Microbiol. Infect. 2004, 10, 248.

32. Wiuff, C.; Madsen, M.; Baggesen, D.L.; Aarestrup, F.M. Quinolone resistance among Salmonella enterica from cattle, broilers, and swine in Denmark. Microb. Drug Resist. 2000, 6, 11-17. [CrossRef] [PubMed]

33. Cattoir, V.; Weill, F.X.; Poirel, L.; Fabre, L.; Soussy, C.J.; Nordmann, P. Prevalence of qnr genes in Salmonella in France. J. Antimicrob. Chemother. 2007, 59, 751-754. [CrossRef] [PubMed]

34. Park, C.H.; Robicsek, A.; Jacoby, G.A.; Sahm, D.; Hooper, D.C. Prevalence in the United States of aac $\left(6^{\prime}\right) \mathrm{Ib}-\mathrm{cr}$ enconding a ciprofloxacin-modifying enzyme. Antimicrob. Agents Chemother. 2006, 50, 3953-3955. [CrossRef] [PubMed]

35. Ribot, E.; Fair, M.A.; Gautom, R.; Cameron, D.N.; Hunter, S.B.; Swaminathan, B.; Barrett, T.J. Standardization of pulsed-field gel electrophoresis protocols for the subtyping of Escherichia coli O157:H7, Salmonella, and Shigella for PulseNet. Foodborne Pathog. Dis. 2006, 3, 59-67. [CrossRef] 